\title{
Physical, chemical and rheological properties of pitomba (Talisia esculenta) seed starch and its application as a thickener and stabilizer in ketchup
}

\author{
Deise Souza de Castro ${ }^{1 *}$, Inacia dos Santos Moreira², Francinalva Cordeiro de Sousa ${ }^{3}$, Wilton Pereira da Silva ${ }^{4}$, \\ Josivanda Palmeira Gomes ${ }^{1}$, Alexandre José de Melo Queiroz ${ }^{1}$, Cleide Maria Diniz Pereira da Silva e Silva ${ }^{4}$, \\ Bruno Adelino de Melo 5
}

\author{
${ }^{1}$ Federal University of Campina Grande (UFCG), Academic Unit of Agricultural Engineering, 58429-140, Campina Grande, \\ PB, Brazil \\ ${ }^{2}$ Federal University of Campina Grande (UFCG), Graduate Program in Process Engineering, Researcher PNPD/CAPES, \\ inaciamoreira@ymail.com, Campina Grande-PB, Brazil \\ ${ }^{3}$ Federal Institute of Education, Science and Technology of Pernambuco (IFPE), Campus of Barreiros, Barreiros, PE, Brazil \\ ${ }^{4}$ Federal University of Campina Grande (UFCG), Academic Unit of Physics, Campina Grande, PB, Brazil \\ ${ }^{5}$ Federal University of Campina Grande (UFCG), Postdoctoral fellow from the National Council for Scientific and \\ Technological Development (CNPq), Campina Grande-PB, Brazil
}

\section{*Corresponding author: deise_castro01@hotmail.com}

\section{Abstract}

The present study aimed to characterize the physical, chemical and rheological properties of starch extracted from pitomba seeds and verify the influence of its addition on the syneresis and viscosity characteristics of ketchup during storage, compared to maize starch. Extraction was performed by grinding the seeds in sodium metabisulfite solution (0.2\%) followed by drying at 50 으. ketchups were formulated with the addition of 0.5 and $1 \%$ pitomba starch, 0.5 and $1 \%$ maize starch and a control formulation. Starch showed low percentages of protein, ashes and lipid, starch purity of $77.78 \%$, amylose of $19.25 \%$, apparent density of $0.46 \mathrm{~g} / \mathrm{cm}^{3}$ and compact density of $0.66 \mathrm{~g} / \mathrm{cm}^{3}$. The starch pastes showed pseudoplastic behavior and imparted significant viscosity, usable in increasing the consistency of fluid foods. Ketchups formulated with addition of pitomba starch showed reduction of syneresis during storage, and the $1 \%$ starch concentration can slow down the syneresis process in ketchup at temperatures of 7 and $25{ }^{\circ} \mathrm{C}$, similar to the stabilizing capacity of maize starch. Ketchup viscosity increased with the addition of pitomba and maize starches, but the highest apparent viscosities were obtained in ketchup with addition of pitomba starch during storage.

Keywords: consistency; flowability; native starch; rheological properties; syneresis.

Introduction

Pitomba (Talisia esculenta) is a fruit native to the Western Amazon and its cultivation is carried out in an unorganized manner, in the North and Northeast regions of Brazil. Pitomba is only consumed fresh because the difficulties to remove the pulp and low yield hamper the processing technologies, but its endocarp represents about $50 \%$ of the total fruit weight, constituting a source of starch (Neri-Numa et al., 2014; Castro et al., 2019).

Starch has been traditionally used to maintain the quality of processed foods, acting as ingredient or additive to improve their properties, serving as thickening and gelling agent, controlling water retention, and stabilizing the texture of processed foods (Zhang et al., 2016). Starch functionality is related to its physical-chemical variations, which are influenced by the molecular structure, plant sources from which it is extracted, gelatinization temperature, gel formation and absence or presence of chemical modification, which characterizes it as either native or modified (Rondán-Sanabria and Finardi-Filho, 2009; Correia et al., 2012; Rani and Chawhaan, 2012; Barbi et al., 2018).

Native starches have limitations in industrial applications due to their high thermal instability and tendency to retrograde during cooling and freezing, but the trend of using natural and clean label ingredients has influenced the use of native starches (Arocas et al., 2009).

Sauces, such as tomato, pepper, white or rose, used to enhance the taste of foods, are frequently consumed during meals and need to meet requirements of viscosity and stability for good acceptance. The main problem associated with sauce quality is the tendency of separation of solids from the liquid phase during storage, so the food industry adds thickening and 
stabilizing ingredients in these formulations and commonly resorts to the use of starches.

The present study aimed to determine the physical, chemical and rheological properties of native starch extracted from pitomba seeds and verify the influence of its addition, compared to maize starch, on the viscosity and stability characteristics of ketchup during storage.

\section{Results and discussion}

Yield, moisture, crude protein, ashes, lipids, total starch and amylose

The results of yield, moisture, and physical-chemical characterization of pitomba starch are presented in Table 1 . The average starch extraction yield was $44.20 \%$, which is close to the results reported by Sajitha and Sasikumar (2015), who observed variation from 42.24 to $48.48 \%$ for starches of different varieties of curcuma. A lower yield, $30.33 \%$, was found by Wani et al. (2016) in starch from fava beans. A moisture percentage of $8.41 \%$ was found in pitomba starch, which fits the specifications recommended by the Brazilian Legislation for commercial starches (maximum moisture content of 14\%) (Brasil, 1987). The low percentages of protein, ashes and lipids reflect a good degree of purity in the sample, a desirable characteristic because the presence of these constituents interferes with starch functional properties. Ascheri et al. (2010) recommend that lipid percentage in the starch should be lower than $1 \%$. Values close to the one found in pitomba starch were reported by Gani et al. (2017), who characterized starch extracted from Himalayan rice cultivars and observed variation from 0.39 to $0.56 \%$, and by Falade et al. (2014), who characterized starch extracted from African rice and observed lipid percentage of $0.40 \%$.

The starch percentage found $(77.78 \%)$ is similar to the one reported by Melo-Neto et al. (2015), for starch extracted from pejibaye fruits $(79.00 \%)$, and higher than the value found for starch from Tommy Atkins mango seed (71.56\%), reported by Mendes et al. (2015). The starch showed $19.25 \%$ of amylose. In the literature, a wide variation of amylose has been reported for different starches, which may be attributed to botanic characteristics and determination methods. However, values close to those found here were reported by Lemos et al. (2017), who obtained amylose percentages of 19.70, 20.46, 16.36 and 11.19 for native starches of corn, potato, banana and cassava, respectively. Amylose proportion has influence on the viscosity of starch pastes and, according to Bello- Perez et al. (2006), the low content of amylose plays an important role in starch physical-chemical and functional properties, because it is the main responsible for the retrogradation phenomenon.

\section{Starch flow properties}

The results for the flow properties of pitomba starch are presented in Table 2. Pitomba starch had low apparent density $\left(0.46 \mathrm{~g} / \mathrm{cm}^{3}\right)$, which is associated with smaller particle size, causing greater porosity during powder rearrangement. The apparent density of pitomba starch is similar to the value of 0.46 $\mathrm{g} / \mathrm{cm}^{3}$ reported by Pachuau et al. (2017), who analyzed the physical properties of starch from a variety of glutinous rice from India.

The low value obtained for compact density reveals the tendency of this starch to become compacted during storage, which can alter the handling properties of the product (Crowley et al., 2014). Das et al. (2015) emphasized the importance of density analysis to determine the type of packaging in the storage of starch samples. According to Santhalakshmy et al. (2015), Hausner ratio (HR) is used to evaluate the cohesiveness of the material, which can be classified as follows: $H R<1.2$ - low cohesiveness, $1.2<\mathrm{HR}>1.4$ - intermediate cohesiveness, and $\mathrm{HR}>1.4$ - high cohesiveness. Thus, pitomba starch has high cohesiveness, which can be a desirable characteristic when it is applied to improve texture in food products, because cohesiveness is related to the tendency of the molecules to remain together. This characteristic could be preserved in the manufacturing of compositions.

The Carr index $(\mathrm{Cl})$ represents the flowability of a sample; $\mathrm{Cl}$ between 15 and 20\% indicates excellent flowability, between 20 and $35 \%$ indicates poor flowability, between 35 and $45 \%$ indicates very poor flowability and $\mathrm{Cl}>45$ is attributed to materials with extremely poor flowability. The results for Carr index characterize pitomba starch as a product of poor flowability, which can be a desirable characteristic for starches used as food thickeners when one intends to make the flow difficult. Machado et al. (2012) analyzed the compressibility index of maize starch and reported $\mathrm{Cl}$ of $36 \%$, classifying it as a product of poor flowability.

\section{Apparent viscosity}

Figure 1 presents the apparent viscosity of pastes of pitomba starch at concentrations of 2, 4 and $6 \%$ under temperatures of 5,15 and $25^{\circ} \mathrm{C}$, as a function of the rotation speeds.

It can be observed that the pastes showed higher apparent viscosity as the starch concentration increased, but the values tended to decrease with increasing rotation speeds, i.e., due to the increase in shear stress, meaning that the samples behaved as a pseudoplastic fluid at all temperatures studied.

According to Shamsudin et al. (2013), the increase of speed generates a force capable of causing structural change, which causes the particles to rearrange in parallel directions, leading to the break of large particles into smaller ones, and these can flow more easily in the direction of the applied stress. Li and Zhu (2018) report reduction of viscosity in pastes of quinoa starch gels with increase in shear rate, which is consistent with the findings of Zhu et al. (2016) and Kong et al. (2010) for starches of rice and amaranth, respectively.

By analyzing the behavior of viscosity as a function of temperature, it is possible to note a considerable reduction in the apparent viscosity of the pastes as the temperature increased. According to Pagno et al. (2014), temperature influences the apparent viscosity and higher viscosity is usually obtained under lower temperatures. Heymam et al. (2014), studying the rheological properties of pastes of modified maize starch, observed that their viscosity was higher at lower temperature, suggesting that the interaction between starch granules is higher under low temperatures because, despite being formed by microgel particles that do not undergo interpenetration, the starch granules overlap, becoming more viscous at lower temperatures. Silva et al. (2018) report higher viscosity in beverages formulated with different thickeners when these were stored under refrigeration temperature.

The starch concentrations used $(2,4$ and $6 \%)$ impart significant viscosity to the starch pastes, suggesting their application to reduce the flowability of liquids. According to $\mathrm{Ai}$ and Jane 
(2015), the viscosity obtained in the paste determines the thickening power of the starch for various industrial applications, but the rheological characteristics of starch pastes depend on several factors, including starch chemical structure, starch concentration, temperature, shear rate and time.

\section{Syneresis}

The syneresis behavior of the ketchup formulations stored for 150 days at temperatures of 7 and $25^{\circ} \mathrm{C}$ is shown in Figure 2 . Storage time progressively influenced the evolution of syneresis in all ketchup formulations at both temperatures studied. The highest percentages of syneresis at all storage times and temperatures were observed in the $\mathrm{C}$ formulation (control), demonstrating the incapacity of the ketchup to preserve isotropy, maintaining the union of phases during storage, without the addition of a stabilizing ingredient in its composition. The formulations PB, MA and MB did not show syneresis immediately after processing at temperatures of 7 and $25{ }^{\circ} \mathrm{C}$, demonstrating good water-binding capacity, forming elastic gels, a characteristic related to the starches added and their capacity to absorb water.

With addition of $0.5 \%$ of pitomba starch (PA), there was a reduction of syneresis in comparison to the control formulation (C), but there were percentages of syneresis immediately after processing, with progressive increase during storage. Arocas et al. (2009), using native starches of corn, waxy corn, potato and rice as thickening and stabilizing agents in white sauce, observed no syneresis in any of the formulations immediately after preparation. However, after being subjected to freeze/thaw cycles, syneresis was observed in sauces with $6 \%$ of corn and potato starches, and these authors point out that the occurrence of syneresis after processing the sauces is associated with structural changes.

The increase of pitomba starch concentration in the ketchup formulation imparted greater stability to the sauce. The addition of $1 \%$ of pitomba starch in the PB formulation was able to delay the syneresis, inhibiting its occurrence immediately after processing, but the progressive increase in syneresis during storage was also observed. According to Stahl et al. (2007), starch gels tend to form rigid structures during cooling, which means that the polysaccharide tends to retrograde as the storage time advances.

By comparing the efficiency of the types of starch used, it can be observed that the additions of $1 \%$ of pitomba and maize starches (PB and $\mathrm{MB}$ ) had the same capacity to reduce syneresis during storage at both temperatures studied, being statistically similar for all storage times. The deceleration observed in the separation of water with the increase in starch concentration can be explained by the high capacity of the starch to absorb water during the gelatinization process.

In the comparison between the syneresis percentages of the formulations for temperatures of 7 and $25^{\circ} \mathrm{C}$ (Figure $2 \mathrm{~A}$ and 2B), higher values of syneresis were found in the ketchup at the higher temperature, which may be associated with the ease of reassociation of amylose and amylopectin chains under room temperature. A similar behavior was reported by Arocas et al. (2009), who studied syneresis of white sauce mixed with corn starch and found higher water release percentages at temperature of $20^{\circ} \mathrm{C}$.

\section{Apparent viscosity of the ketchup}

The behavior of the apparent viscosity of ketchups stored for 180 days under temperature of $7{ }^{\circ} \mathrm{C}$ is shown in Figure 3. In all formulations and storage times, the apparent viscosity of the samples decreased with the increase in deformation rate, an indication of the accommodative pattern of the structure of the ketchups, proportional to the increase in the applied shear stress, characteristic of the pseudoplastic behavior of the samples.

According to Mandala et al. (2004), the pseudoplastic behavior of starch-containing solutions occurs especially when the granules are significantly swollen, which leads to deformation when subjected to shear forces. In a comparison of the initial apparent viscosity values of the ketchup formulations between 0 and 30 days (Figure $3 \mathrm{~A}$ and $\mathrm{B}$ ), an elevation can be noted after storage under the temperature of $7{ }^{\circ} \mathrm{C}$, which is related to the formation of a more rigid structure established by the retrogradation process, besides the effect of refrigeration on the increase in the firmness of pastes and sauces.

Increase of viscosity in the sauces at the initial times of storage was also observed by Sikora et al. (2007), studying the rheological and sensory properties of dessert sauces thickened by starch-xanthan gum combinations. These authors reported that the storage of sauces may result in a slow mutual organization of the ingredients which influence the structure of the food, causing changes in its viscosity.

After 30 days, all ketchup formulations showed a reduction in the initial viscosity. The addition of starch influenced the increase of viscosity, and alterations were observed from the addition of $0.5 \%$ of pitomba and maize starches. Diantom et al. (2017) also observed an increase in the apparent viscosity of tomato sauce with the addition of $0.5 \%$ of locust bean gum, potato protein, soy protein and potato fiber, which imparted higher flow resistance to the sauce. The highest initial apparent viscosities of the ketchups stored at $7{ }^{\circ} \mathrm{C}$ were observed in the formulations mixed with pitomba starch ( $\mathrm{PA}$ and $\mathrm{PB}$ ), possibly related to the composition of this starch, which has high content of amylopectin, with the ability to form more rigid gels due to the presence of a large number of branched chains that impart greater resistance to flow.

The behavior of the apparent viscosity of ketchups stored at 25 ${ }^{\circ} \mathrm{C}$ for 150 days is shown in Figure 4. Under this storage condition, the ketchups also showed pseudoplastic behavior, with reduction of apparent viscosity as the shear stress increased. Reduction of viscosity occurs due to the progressive orientation towards the flow, causing the disaggregation of the molecules formed from the sauce structure organization (Kim and You, 2009).

Increments in the initial apparent viscosity of all ketchup formulations were also observed after 30 days of storage, but at the temperature of $25 \stackrel{\circ}{\circ}$ the ketchups showed greater increase of apparent viscosity in all formulations, compared to the samples at temperature of $7 \stackrel{\circ}{\circ}$, demonstrating lower influence of this temperature on the formation of rigid structures of pastes and sauces. According to Constenla et al. (1989), the reduction of viscosity with increasing temperature can be attributed to the increment in intermolecular distances in the starch, as a result of thermal expansion. 
Table 1. yield and physical-chemical characterization of pitomba starch.

\begin{tabular}{|l|l|}
\hline Parameters & Result \\
\hline Yield (\% d.b.) & 44.20 \\
\hline Moisture (\% w.b.) & $8.41 \pm 0.07$ \\
\hline Protein (\%) & $4.03 \pm 0.05$ \\
\hline Ashes (\%) & $0.63 \pm 0.05$ \\
\hline Lipids (\%) & $0.39 \pm 0.02$ \\
\hline Starch (\%) & $77.78 \pm 0.07$ \\
\hline Amylose (\%) & $19.25 \pm 0.17$ \\
\hline
\end{tabular}

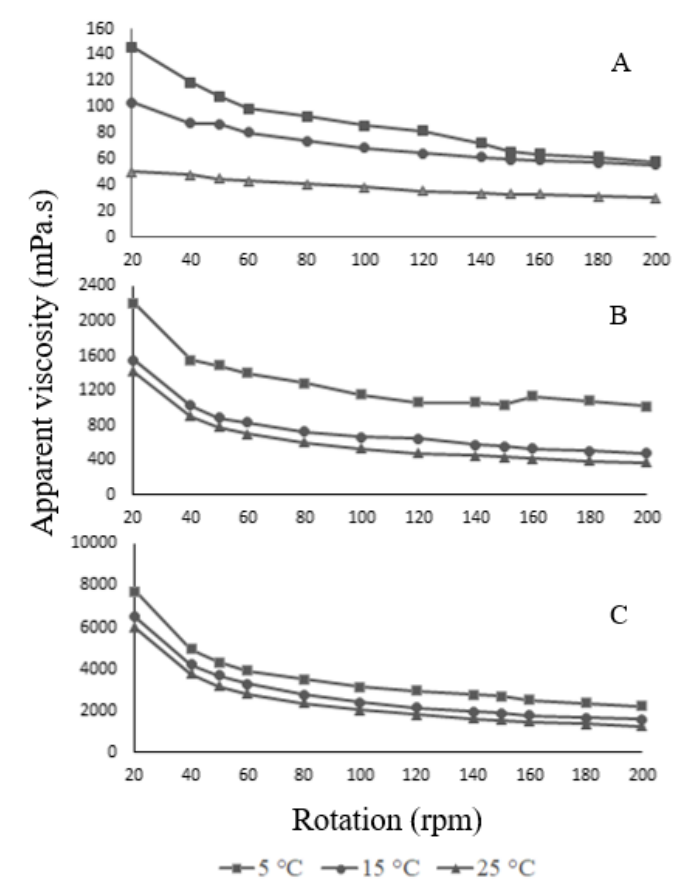

Figure 1. Apparent viscosity (mPa.s) of pitomba starch pastes at concentrations of $2 \%(\mathrm{~A}), 4 \%(\mathrm{~B})$ and $6 \%$ (c) under different temperatures and rotation speeds.

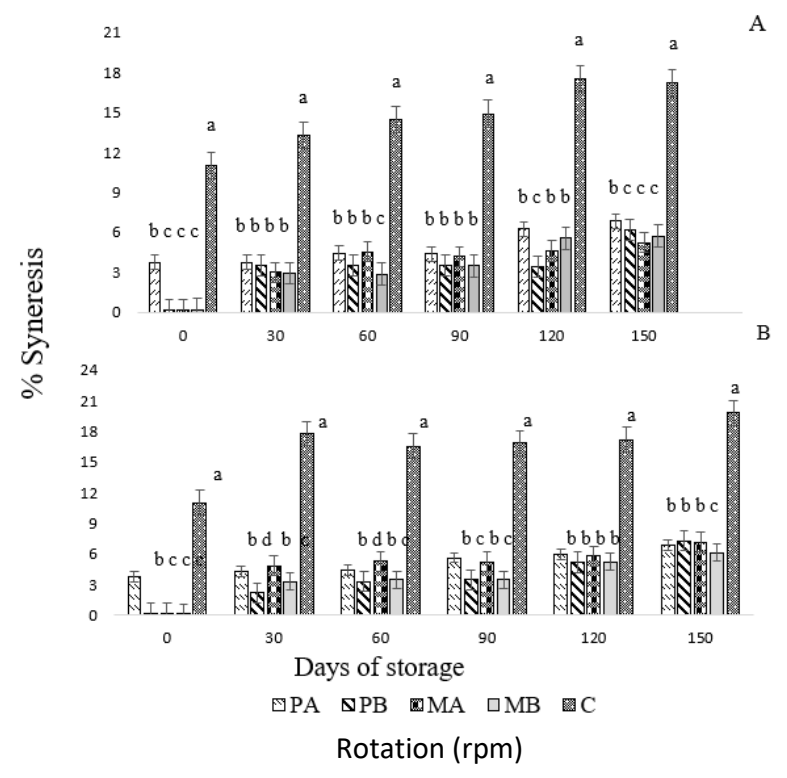

Figure 2. Evolution of syneresis in ketchups stored for 150 days at $7(\mathrm{~A})$ and $25^{\circ} \mathrm{C}(\mathrm{B}) .{ }^{*}$ Columns identified with identical letters at the same storage time do not differ statistically by Tukey test $(p \leq 0.05) n=3$. 

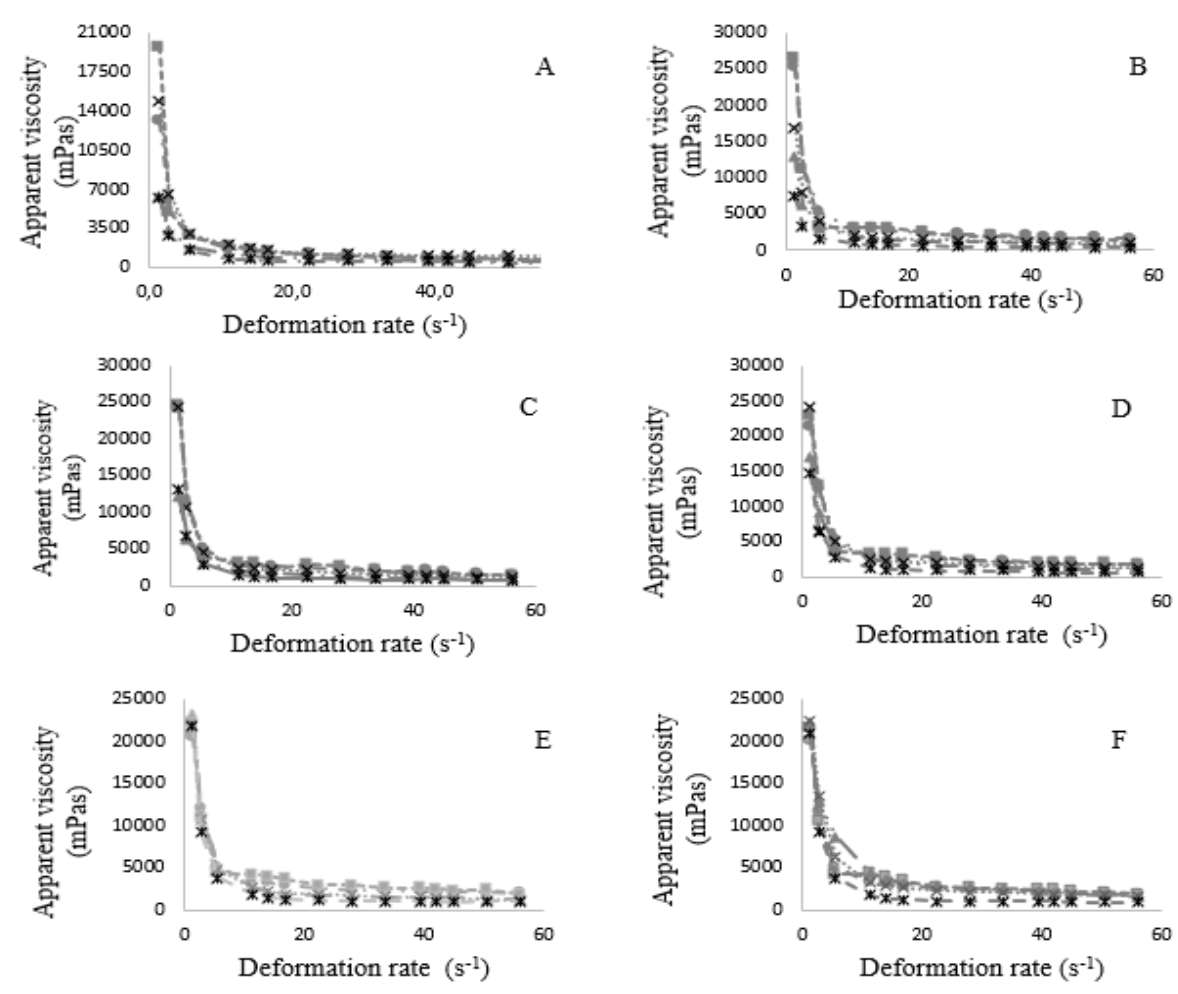

- $\mathrm{PA}-\rightarrow-\mathrm{PB} \longrightarrow \mathrm{MA} \cdots \times \cdots \mathrm{MB}-*-\mathrm{C}$

Figure 3. Behavior of apparent viscosity in ketchups stored for 0 (A), 30 (B), 60 (C), 90 (D), 120 (E) and 150 (F) days at $7^{\circ} \mathrm{C}$.
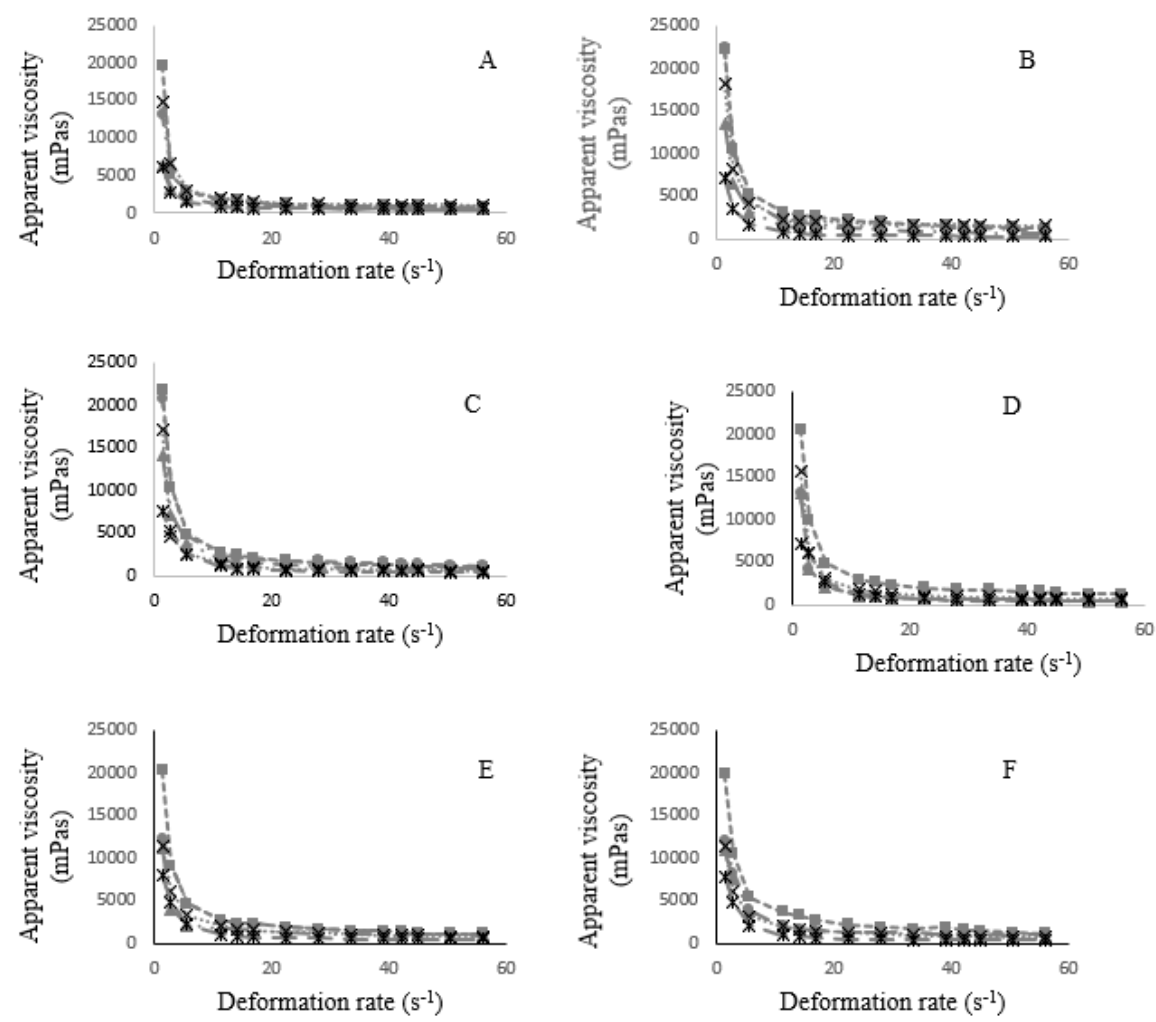

$$
\text { - }-\mathrm{PA} \quad--\mathrm{mB} \rightarrow \cdot \mathrm{MA} \quad \cdots \times \cdots \cdot \mathrm{MB}-*-\mathrm{C}
$$

Figure 4. Behavior of apparent viscosity in ketchups stored for 0 (A), 30 (B), 60 (C), 90 (D), 120 (E) and 150 (F) days at $25^{\circ} \mathrm{C}$. 
Table 2. flow properties of pitomba starch.

\begin{tabular}{|l|l|}
\hline Parameters & Result \\
\hline Apparent density $\left(\mathrm{g} / \mathrm{cm}^{3}\right)$ & 0.46 \\
\hline Compact density $\left(\mathrm{g} / \mathrm{cm}^{3}\right)$ & 0.66 \\
\hline Hausner ratio & 1.43 \\
\hline Carr index $(\%)$ & 30 \\
\hline
\end{tabular}

\section{Materials and methods}

Pitomba fruits were purchased at the State Supply Center (CEASA) of the Recife city, Pernambuco, Brazil (8.07164S $34.9425736,49 \mathrm{~W})$. The fruits were selected according to the yellowish-brown color of the peel and sent to the Laboratory of Storage and Processing of Agricultural Products of the Federal University of Campina Grande, Campina Grande, Paraíba, Brazil (7.2171315S 35.9100279,97W).

\section{Starch}

To obtain native starch from pitomba, the fruit was manually peeled and the seed (endocarp), involved by the pulp, was immersed in sodium hydroxide solution (8\%) for $30 \mathrm{~min}$., followed by successive washings in running water to completely remove the pulp. Seeds resulting from the pulping process were neutralized in citric acid solution (4\%) for 30 seconds. Starch extraction was carried out as described by Castro et al. (2019), through the immersion of seeds in sodium metabisulfite $(0.2 \%)$ at $1: 2$ proportion $(\mathrm{m} / \mathrm{v})$ for $72 \mathrm{~h}$. at $4{ }^{\circ} \mathrm{C}$, followed by grinding of the mixture and sieving. The filtrate was left at rest for 1 hour, the supernatant was discarded, the starch paste was then washed in $0.2 \%$ metabisulfite solution, decanted ( 1 hour), and the supernatant was discarded twice. After decantation, the starch paste was centrifuged at $3000 \mathrm{rpm}$ for $3 \mathrm{~min}$. and the supernatant was discarded. The starch resulting from centrifugation was washed with alcohol (95\%), centrifuged, with supernatant discarded 3 times, and dried in a forced air circulation oven at $50{ }^{\circ} \mathrm{C}$ for $12 \mathrm{~h}$. The starch was ground in a domestic processor (Pratic Blender BLD300) to obtain the powder.

Yield, determination of moisture, crude protein, ashes, lipids, total starch and amylose

Starch extraction yield was evaluated based on the final mass of starch (d.b.) divided by the mass of endocarp used in the extraction (d.b.) and expressed in percentage. The contents of moisture, protein and ashes were determined according to the methods described by AOAC (2002): moisture in an oven at 105 \pm 3 으, procedure $n^{\circ} 925.09$ (32.13); protein by Kjeldahl, using a conversion factor of 6.5 , procedure $n^{\circ} 991.20$ (33.2.11); ashes in a muffle furnace at $550 \pm 3{ }^{\circ} \mathrm{C}$, procedure $n^{\circ} 923.03$ (32.1.05). Lipid content was determined by the method of Bligh and Dyer (1959). Starch content was evaluated according to the methodology proposed by the Adolfo Lutz Institute (IAL, 2004), whose principle is the detection of glucose produced by the hydrolysis of starch molecules, whereas amylose was quantified by the colorimetric method with results calculated based on a standard curve constructed with pure amylose (Sigma), according to the methodology of Zavareze (2009).

\section{Starch flow properties}

Apparent density was determined according to Souza et al. (2010), by weighing $5 \mathrm{~g}$ of the pitomba starch sample in a 10-mL graduated cylinder, with no compaction, and calculated according to Equation 1. The starch contained in the cylinder was compacted by manually tapping the cylinder 50 times on a bench surface from a height of approximately $5 \mathrm{~cm}$, to determine the compact density according to Equation 2. With these values of apparent and compact densities, the Hausner ratio and Carr index were calculated using Equations 3 and 4.

$$
\begin{gathered}
p a=\frac{m}{v} \\
\rho c=\frac{m}{v_{a}} \\
H R=\frac{\rho c}{\rho a} \\
C I=\frac{\rho c-\rho a}{\rho c}
\end{gathered}
$$

Where:

$\rho_{a}=$ apparent density $\left(\mathrm{g} . \mathrm{cm}^{-3}\right)$

$m=$ mass $(\mathrm{g})$;

$v=$ volume $\left(\mathrm{cm}^{3}\right)$;

$\rho_{c}=$ compact density $\left(\mathrm{g} . \mathrm{cm}^{-3}\right)$

$v_{a}=$ volume after compaction $\left(\mathrm{cm}^{3}\right)$;

$\mathrm{HR}=$ Hausner ratio;

$\mathrm{Cl}=$ Compressibility index $(\%)$

\section{Starch apparent viscosity}

Solutions containing 2, 4 and $6 \%$ of starch were prepared, subjected to gelatinization in water bath $\left(100^{\circ} \mathrm{C}\right)$ for $30 \mathrm{~min}$. and then cooled to room temperature. The cooled pastes were subjected to reading in a programmable viscosimeter DVII+PRO, from Brookfield, at temperatures of 5,15 and $25^{\circ} \mathrm{C}$, under rotation speeds of $20,40,50,60,80,100,120,140,150$, 160, 180 and $200 \mathrm{rpm}$.

\section{Preparation and storage of ketchups}

Ketchups were prepared with tomato pulp (50\%), water (25\%), sugar $(15 \%)$, vinegar $(5 \%)$, salt $(3 \%)$ and condiments $(2 \%)$. Five formulations were prepared with different percentages of pitomba starch and maize starch (commercial) added to the standard formulation. Pitomba starch was subjected to a toxicity test according to Meyer et al., 1982, and presented DL 50 $1036,46 \mu \mathrm{g} \mathrm{mL}{ }^{-1}$, considered as non-toxic in compliance with Brazilian legislation for addition to food products. Ketchup formulations were identified as: PA - $0.5 \%$ pitomba starch, PB - 
$1 \%$ pitomba starch, $\mathrm{MA}-0.5 \%$ maize starch, $\mathrm{MB}-1 \%$ maize starch, and C - control.

After cooking, when the formulations reached the desired concentration ( $35^{\circ}$ Brix), the sauces were placed in $125-\mathrm{mL}$ polypropylene plastic containers with lid and stored at temperatures of 7 and $25^{\circ} \mathrm{C}$ for 150 days.

\section{Syneresis}

The stabilizing capacity of the starches in the ketchups was determined by quantifying the syneresis using the drainage method, by weighing 30 grams of the ketchup sample on a filter paper at the upper part of a funnel attached to a $100-\mathrm{mL}$ Erlenmeyer flask, at 4 o $\mathrm{C}$ for $5 \mathrm{~h}$. The index of syneresis was calculated according to Riener et al. (2010), using Equation 5:

(\%) Syneresis $=\frac{\text { mass of water released in filtration }}{\text { initial mass }} * 100$

(5)

\section{Apparent viscosity of ketchups}

The apparent viscosity of ketchups was evaluated to determine the thickening capacity of the starch in the formulations. A programmable viscosimeter (DV-II+PRO - Brookfield) was used at temperatures of 7 and $25^{\circ} \mathrm{C}$, with rotation speeds of 5,10 , $20,40,50,60,80,100,120,140,150,160,180$ and $200 \mathrm{rpm}$.

\section{Statistical analysis}

The results were analyzed by descriptive statistics, using the measures of central tendency and data variability.

\section{Conclusions}

Pitomba starch showed low flowability and high cohesiveness, low percentages of lipids, ashes and protein. When gelatinized, the starch pastes showed pseudoplastic behavior and imparted good apparent viscosity, suggesting applications to increase the consistency of liquids, associated with a considerable reduction of viscosity with increasing temperatures.

Addition of pitomba starch to ketchup formulations led to higher apparent viscosity, compared to maize starch, and was able to delay syneresis in the sauces, which was increased with the increment in storage temperature.

\section{Acknowledgments}

To the National Council for Scientific and Technological Development (CNPq) for granting the scholarship to the first author. To the members of the Laboratory of Storage and Processing of Agricultural Products of the Academic Unit of Agricultural Engineering, and to the Federal University of Campina Grande for providing the infrastructure used in the study.

\section{References}

AOAC-Association of Official Analytical Chemistry. 2002 Official methods of analysis of association of official analytical chemist international. Food composition; Additives; Natural contaminants. 17th ed. Arlington: AOAC (2).

Ari Y, Jane AJL (2015). Gelatinization and rheological properties of starch: review. Starch / Stärke, 54, 213-224.
Arocas A, Sanz T, Fiszman SM (2009). Clean label starches as thickeners in white sauces. Shearing, heating and freeze/thaw stability. Food Hydrocolloids, 23, 2031-2037.

Ascheri DPR, Moura WS, Ascheri JLR, Carvalho CWP (2010). Caracterização física e físico-química de rizomas e amido do lírio-do-brejo (Hedychium coronarium). Pesquisa Agropecuária Tropical, 40, 159-166.

Barbi RCT, Teixeira GL, Hormung PS, Ávila S Ribanl RH (2018). Eriobotrya japonica seed as a new source of starch: Assessment of phenolic compounds, antioxidant activity, thermal, rheological and morphological properties. Food Hydrocolloids, 77, 646-658.

Bello-Pérez LA, Montealvo MGM, Acevedo EG (2006). Almidón: definición, estructura y propriedades. In: Lajolo, FM., Menezes, EW, Carbohidratos em Alimentos Regionales Iberoamericanos. Editora da USP, São Paulo.

Bligh EG, Dyer WJ (1959). A rapid method of total lipid extraction and purification. Canadian Journal of Biochemistry and Physiology, 37, 911-917.

BRASIL. Decreto no 12.486 de 20 de outubro de 1987. Diário Oficial do Estado de São Paulo. 21 out, 1987, p.20. normas relativas a alimentos e bebidas.

Castro DS, Moreira IS, Silva LMM, Lima JP, Silva WP, Gomes JP, Figueirêdo RMF (2019). Isolation and Characterization of starch from pitomba endocarp. Food Research International, 124, 181-187.

Constenla DT, Lozanno JE, Crapiste, GH (1989). Thermophysical properties of clarified apple juice as a function of concentration and temperature. Journal of Food Science, 54, $663-668$.

Correia PR, Nunes MC, Beirão-da-Costa ML (2012). The effect of starch isolation method on physical and functional properties of Portuguese nuts starches. I. Chestnuts (Castanea sativa Mill. var. Martainha and Longal) fruits. Food Hydrocolloids, 27, 256-263.

Crowley SV, Gazi I, Kelly AL, Huppertz TO, Mahony JA (2014). Influence of protein concentration on the physical characteristics and flow properties of milk protein concentrate powders. Journal of Food Engineering, 135, 3138.

Das D, Jha S, Kumar KJ (2015). Isolation and release characteristics of starch from the rhizome of Indian Palo. International Journal of Biological Macromolecules, 72, 341346.

Diantom A, Cuti E, Carini E, Vittadini E (2017). Effect of added ingredients on water status and physico-chemical properties of tomato sauce. Food Chemistry, 236, 101-108.

Falade, KO, Semon, M, Fadairo, OS, Oladuna. O, Orou, KK (2014). Functional and physico-chemical properties of flours and starches of African rice cultivars. Food Hydrocolloids, 39, $41-$ 50.

Gani A, Ashwar BA, Akhter G, Shah A, Wani, IA, Masoodi FM (2017). Physico-chemical, structural, pasting and thermal properties of starches of fourteen Himalayan rice cultivars. International Journal of Biological Macromolecules, 95, 1101 $-1107$.

Heymam B, Vos WH, Meeren PVD, Dewettinck K (2014). Gums tuning the rheological properties of modified maize starch pastes: Differences between guar and xanthan. Food Hydrocolloids, 39, 85-94. 
IAL-Instituto Adolfo Lutz. 2004. Normas analíticas: métodos químicos e físicos para análise de alimentos. 2. ed. São Paulo.

Kim W, Yoo, B (2009). Rheological behaviour of acorn starch dispersions: effects of concentration and temperature. International Journal of Food Science and Technology, 44, 503-509.

Kong X, Kasapis S, Bertoft E, Corke H (2010). Rheological properties of starches from grain amaranth and their relationship to starch structure. Starch, 62, 302-308.

Lemos PVF, Barbosa LS, Ramos IG, Coelho RE, Druzian JI (2017). The important role of crystallinity and amylose ratio in thermal stability of starches. Journal of Thermal Analysis and Calorimetry, 130, 1-13.

Li G, Zhu F (2018). Rheological properties in relation to molecular structure of quinoa starch. International Journal of Biological Macromolecules, 144, 767-775.

Machado TC, Silveira RL, Laporta LV, Santos MR (2012). Influência de excipientes na manipulação de cápsulas de furosemida. Disciplinarum scientia, 13, 27-39.

Mandala IG, Savvas TP, Kostaropoulos AE (2004). Xanthan and locust bean gum influence on the rheology and structure of a white model-sauce. Journal of Food Engineering, 64, 335-342.

Melo-Neto BA, Barbosa AZ, Leite CXS, Almeida PF, Bonomo RCF, Pontes KV (2015). Chemical composition and functional properties of starch extracted from the pejibaye fruit (Bactris gasepaes Kunt.). Acta Scientiarum. Technology, 37, 105-110.

Mendes MLM., Ribeiro APL, Almeida EC (2015). Efeito da acidificação nas propriedades físico-químicas e funcionais do amido de sementes de manga (Mangifera indica L.), variedade Tommy Atkins. Ceres, 62, 225-232.

Meyer, BN., Ferrigni, NR., Putnam, LB., Jacobsen, LB., Nichols, DE., Mclaughlin, JL. (1982). Brine shrimp: A convenient general bioassay for active plant constituents. Journal of Medicinal Plant and Natural Product Research, 45, 31-4.

Neri-Numa IA, Carvalho-Silva LB, Ferreira JEM, Machado ART, Malta LG, Ruiz ALTG, Carvalho JE, Pastore GM (2014). Preliminary valuation of antioxidant, antiproliferative and antimutagenic activities of pitomba (Talisia esculenta). Food Science and Technology, 59, 1233-1238.

Pachuau L, Dutta RS, Roy PK, Kalita P, Lalhlenmawia H (2017). Physicochemical and disintegrant properties of glutinous rice starch of Mizoram, India. International Journal of Biological Macromolecules, 95, 1298-1304.

Pagno CH, Souza LF, Flores SH, Jong EV (2014). Desenvolvimento de espessante alimentar com valor nutricional agregado, destinado ao manejo da disfagia. Ciência Rural, 44, 710-716.

Rani A, Chawhaan PH (2012). Extraction and scanning electron microscopic studies of Curcuma angustifolia Roxb. starch. Indian Journal Natural Products and Resource, 3, 407-410.
Riener J, Noci F, Cronin DA, Morgan DJ, Lyng, JG (2010). A comparison of selected quality characteristics of yoghurts prepared from thermosonicated and conventionally heated milks. Food Chemistry, 119, 1108-1113.

Rondán-Sanabria GG, Finardi-Filho F (2009). Physical-chemical and functional properties of maca root starch (Lepidium meyenii Walpers). Food Chemistry, 114, 492-498.

Sajitha PK, Sasikumar, B (2015). Qualitative and Quantitative Variation in Starch from Four Species of Curcuma. Cytologia, $80,45-50$.

Santhalakshmy S, Bosco SJD, Francis S, Sabeena M (2015). Effect of inlet temperature on physicochemical properties of spraydried jamun fruit juice powder. Powder Technology, 274, 3743.

Shamsudin R, Ling CS, Adzahan NM, Daud WRW (2013). Rheological properties of ultraviolet-irradiated and thermally pasteurized Yankee pineapple juice. Journal of Food Engineering, 116, 548-553.

Sikora M, Kowalski S, Tomasik P, Sady M (2007). Rheological and sensory properties of dessert sauces thickened by starchxanthan gum combinations. Journal of Food Engineering, 79, 1144-1151.

Silva RR, Assumpção $M$, Fernandes PM, Feliciano TA, Vieira CR, Lomeu FLRO (2018). Efeito da utilização de gomas na viscosidade e nas características sensoriais de shake à base de farinha de banana verde. Brazilian Journal of Food Technology, 21, e2016052.

Souza RLA, Oliveira LSC, Silva FLH, Amorim BC (2010). Caracterização da poligalacturonase produzida por fermentação semi-sólida utilizando-se resíduos de maracujá como substrato. Revista Brasileira de Engenharia Agrícola e Ambiental, 14, 987-992.

Stahl JA, Lobato LP, Bochi VC, Kubota EH, Gutkoski LC, Emanuelli T (2007). Physicochemical properties of Pinhão (Araucaria angustifolia, Bert, O. Ktze) starch phosphates. LWT - Food Science and Technology, 40, 1206-1214.

Wani IA, Sogi DS, Hamdani AM, Gani A, Bhat NA, Shah A (2016). Isolation, composition, and physicochemical properties of starch from legumes: A review. Starch / Stärke, 68, 834-845.

Zavareze ER, Ei Halal SLM, Ereira JM, Radunz AL, Elias MC, Dias, ARG (2009). Caracterização química e rendimento de extração de amido de arroz com diferentes teores de amilose. Brazilian Journal of Food Technology, 2, 24-30.

Zhang H, Yin L, Zheng Y, Shen J (2016). Rheological, textural, and enzymatic hydrolysis properties of chickpea starch from a Chinese cultivar. Food Hydrocolloids, 54, 23-29.

Zhu F, Bertoft E, Li G (2016). Morphological, Thermal, and Rheological Properties of Starches from Maize Mutants Deficient in Starch Synthase III. Journal of Agricultural and Food Chemistry, 64, 6539-6545. 